\title{
Changing leadership and rural power structure
}

\author{
L. Mozumdar, R.N. Ali, K.S. Farid and M.S. Kabir \\ Department of Rural Sociology, Bangladesh Agricultural University, Mymensingh-2202, Bangladesh
}

\begin{abstract}
The present study attempts to assess the nature of changes occurred in the leadership pattern of rural power structure in Bangladesh. A complete household survey of Sutiakhali Namapara village in Sadar Upazila of Mymensingh district was undertaken to identify rural leaders. Among 92 households, a total of 18 leaders were identified by using the positional, the reputational, and the issue participation approach. The information about the changing aspects of rural power structure and the leadership pattern were collected by formal and informal interviews, Focus Group Discussions (FGDs), participant observation, and storytelling. Findings showed that majority of the leaders were young (55.56\%), had no specific lineage status (38.89\%) and most of them $(38.89 \%)$ were businessmen. Education, personal qualities and affiliation with major political parties were more important factors influencing rural leadership. A remarkable change occurred in the power structure of rural Bangladesh during the last decade, more specifically from 2001 to 2007. Among the elites, the younger ones were dominating the villages, whereas, the older ones were losing the elite status, because of their lack of positional status and power. It also revealed that the rural leaders changed their policy to create and sustain power, such as building business associations, forming party networks involving with different government and nongovernment organizations and maintaining a good link with local Member of Parliament etc. Finally, it can be said that a significant change occurred in leadership pattern and power structure of rural Bangladesh.
\end{abstract}

Keywords: Power structure, Leadership, Lineage status, Personal qualities

\section{Introduction}

The present history of Bangladesh possesses a number of challenges to the traditional understanding of rural political change. A sociological understanding of local political processes and the local power structure is a relative rarity in the Bangladesh context. A particular gap in this regard is the interplay of political dynamics at the local level and its interaction with the state and wider actors. However, there is an important reason why a study of the changing rural power structure promises to be particularly illuminating towards an understanding of political change at the local level (Rahman 2002). Understanding the potential of the rural power structure is a key analytical, and indeed political, imperative towards the goal of democratization of Bangladesh society. The concept of power is a central one within the social sciences. More recently, a work on power by social theorists have broadened the discussion. A. Gramsci's (1988) ideas about power emphasized its influence as a totalizing force-hegemony-which allowed the state and/or a popular majority to dominate society through a pervasive institutional power, thereby repressing citizens who may hold alternative or contradictory opinions about state actions. This has led some researchers to focus on social movements and other forms of collective action or resistance. The another key influential theorist of power is M. Foucault (1980), who rejected a 'binary' view of power (for example, domination and resistance) and showed instead the ways in which power is multidimensional, strategic, and bound in constant processes of discipline and persuasion, which maintains the positioning of those with and without power. As such, power is not simply embedded in structural relations, but is also constituted through language and through everyday practices. This latter idea has also been elaborated by P. Bourdieu (1989), who has also placed an emphasis the importance of 'symbolic power'. 
A related concept which is relevant to this study is that of the 'power elite'. The term denotes the people at the top of the major institutional hierarchies of a society, whose shared interests lead them to form an overlapping clique influencing major decisions. These elite maintains social stratification and hierarchy through the use of force, making decisions that transcend ordinary social environments to affect the lives of people with whom they may not have any direct contact, such as senior politicians or directors of multinational corporations. An understanding of the local power structure can usefully draw upon many of these concepts. The local elite, in turn linked to national and international levels of institutional hierarchy, help create and maintain a local power structure based on economic, political and social relationships. In particular, the distinction between 'power over' and 'power to' made by Rowlands (1995) is useful because it separates the kind of power that allows one person or group to dominate another from the kind of power that allows a person or group to challenge and change their situation. The historical analysis of the pattern of leadership in rural Bangladesh informs us that no single variable is responsible for construction of the leaders in rural area. Member of a strong lineage or descent group, control over agricultural land, right over human power, technological skills, demographic strength constitute a general background of leader. In rural Bangladesh, early studies (Karim, 1990) revealed the position of leaders till 1950s to 1990s. In 1950s to 1970s, there was a traditional pattern of leadership in rural Bangladesh. During that time, early settlers in the village area grasped the political power and social status through the proximity of local Hindu zaminders as revenue collector.

The research literature on Bangladesh normally refers to the local power structure as the configuration of the local elite, their networks and resources, and links with both formal institutions (such as local government structures) and informal institutions (such as indigenous dispute settlement mechanisms and traditions of patron-clientelism). Rahman (1981) found that primary economic strength and social status of local leaders depended on the extent of land ownership. However, level of education was also an important asset for attaining leadership and education had a direct correlation with land ownership patterns. Such leaders have close links with the administration and non-agricultural sources of income. Control over land, linkage with administration, and non-agricultural sources of income are three important variables to get access to the rural power structure. Khan (1989) presented village fieldwork data from Comilla which questioned the assumption that the rich peasant/landlord class had 'captured' irrigation facilities and found them distributed relatively openly to all landholding groups. Lewis (1991) also found class roles and relations less circumscribed at the level of the village than presented in much of this earlier political economy literature, with new agricultural technologies opening up both more and new kinds of economic opportunities for some nontraditional power holders in rural areas. Key to this analysis was the observation that the importance of land as the main factor of productionand, therefore, as an index of rural power-was beginning to decline. So, keeping the above view in mind the present study was undertaken to indicate the process of change in the leadership pattern and to identify the nature of the changing categories of leadership in the rural power structure.

\section{Materials and Methods}

For the present study Sutiakhali Namapara village was selected randomly from purposively selected Sadar upazila of Mymensingh district. The study was based on a set of field level primary data collected from the respondents with the help of interview schedule. The data were collected during the period from February to April, 2008 in a regular basis by the researcher himself. The head of each household in the study village was the population of the present study. At the first stage, for the identification of rural leader a complete household 
survey of the village was conducted through a structured interview schedule and total 92 households were found in the study village. At the second stage, the rural leaders were identified by using the following three approaches:

\section{A. The positional approach}

This approach is used to identify those persons who hold some positions of authority and formal power in institutions and organizations of the community. Adopting the approach, 11 positional leaders were found in the study area. Among these positional leaders 2 were UP (Union Parishad) leaders, 4 were NGO leaders and 5 were institutional leaders.

\section{B. The reputational approach}

These leaders have had reputation but no formal position of authority, and they exerted enormous power and influence in village affairs. Seven (7) reputational leaders were identified in the study village by using this approach. They were informal party leaders and informal village leaders.

\section{The issue-participation approach}

This approach looks for those who participate in the decision-making of social issues. This approach firstly devoted to identify the issues of social significance and then to find out those persons who participate in those issues and makes decisions for the community. The researcher found that the reputational (7) and the positional (11) leaders participated in the village issues and tried to comprehend it to make a judgment.

So, adopting these three approaches mentioned above total 18 leaders (11 positional leaders and 7 reputational leaders) was identified in the study area.

At the third stage, another structured interview schedule was administered among the leaders identified through the household interview schedule. The interview schedule consists of the sections designed in the household interview schedule with an addition of some new sections. Both the qualitative and quantitative data were collected for the present study with the help of Interviewing (structured and semi-structured interview schedule), Focus Group Discussions (Key informants schedule), Participant observations (Researcher himself stayed at study village), and Storytelling and informal interviews.

After collecting requisite data, they were edited and initially collected data in local units were converted into standard international units to improve their quality. Then the edited data were compiled, classified, tabulated and analyzed by using SPSS (Statistical Package for Social Sciences). For analysis and presentation of data different statistical tools like percentages, ratios, mean, etc. were applied and for qualitative data other qualitative tools like weighted score and rank order also used. Tabular analyses of significant items have been depicted through charts because of their simplicity to use and understand. In the process of ranking three priorities were sorted for specific item in order of importance by asking the respondents of this study, and after giving weight score (3 for priority I, 2 for priority II, 1 for priority III) to each of the three priorities, the final rank order was drawn. 


\section{Results and Discussion}

\section{The influential leaders of Sutiakhali Namapara}

The leader is an essential part of the mechanism of the community. Demographic variables give some insight into the social and economic background of the rural leadership (Sirsikar, 1970). Attempts were made in this section to locate the socio-economic background of the leaders which are shown in Table 1.

\section{Table 1. Socio-economic and political background of rural leaders}

\begin{tabular}{|c|c|c|}
\hline Variables & Frequency & Percentage (\%) \\
\hline \multicolumn{3}{|l|}{ Age Group ( in years ) } \\
\hline $20-40$ & 10 & 55.56 \\
\hline $41-55$ & 5 & 27.78 \\
\hline 56 and above & 3 & 16.66 \\
\hline \multicolumn{3}{|l|}{ Education } \\
\hline Illiterate & 1 & 5.56 \\
\hline Primary (1-5 ) & 2 & 11.11 \\
\hline Secondary (6-10) & 5 & 27.78 \\
\hline Passed HSC & 5 & 27.78 \\
\hline Graduate and above & 5 & 27.78 \\
\hline \multicolumn{3}{|l|}{ Occupation } \\
\hline Agriculture (+Business) & 4 & 22.22 \\
\hline Business & 7 & 38.89 \\
\hline Service(+ Business) & 5 & 27.78 \\
\hline Others & 2 & 11.11 \\
\hline \multicolumn{3}{|l|}{ Lineage Status } \\
\hline Mondal & 4 & 22.22 \\
\hline Sarkar & 3 & 16.67 \\
\hline Sheikh & 2 & 11.11 \\
\hline Bepari & 2 & 11.11 \\
\hline Others & 7 & 38.89 \\
\hline \multicolumn{3}{|l|}{ Personal Qualities } \\
\hline $\begin{array}{l}\text { Knowledgeable and have the ability to control } \\
\text { over manpower }\end{array}$ & 6 & 33.33 \\
\hline Honest and better oral present ability & 5 & 27.78 \\
\hline Technical skills and others & 7 & 38.89 \\
\hline \multicolumn{3}{|l|}{ National Political Stand } \\
\hline Ruling party activities & 7 & 38.89 \\
\hline Opposite party activities & 7 & 38.89 \\
\hline No party affiliation & 4 & 22.22 \\
\hline Total & 18 & 100.00 \\
\hline
\end{tabular}

Source: Field Survey, 2008

Age-group variables indicate that most of the leaders were relatively young. The community members having higher education (27.78\%) and personal qualities were emerging as community leaders. In the study village, it was found that majority of the leaders were businessmen (38.89\%) and $27.78 \%$ leaders were service holder and business was their additional source of income. Whereas, the minority of the leaders was peasants and business 
was their secondary occupation. The dominant gosthi leaders (22.22\%) were not in the nodal point of power. Most of the leaders (38.89\%) originated from those families who had no remarkable gosthi status. The exercise of power, control of village, its conflict resolution, political activities, government development projects and linkage with the formal government offices were no longer the major works of land-rich and less educated higher gosthi leaders, but young mediocre and higher educated ward level ruling party activist having greater personal quality and communication with the national leaders more or less exercising power and were taking part in the decision making procedures. At present, rural leadership shifts from traditional to its modern fashion in Sutiakhali Namapara (Mozumdar, 2008).

\section{Factors influencing rural leadership}

There were several factors in case of holding the rural leadership. An attempt was made to determine the most pertinent factors in this regard. From Table 2, it is found that the first and foremost factor in case of holding the rural leadership was 'the level of education'. The second and third important factors in this respect were 'personal quality' and 'affiliation with political party' respectively (Mozumdar, 2008).

Table 2. Factors Responsible For Rural Leadership and Holding Power

\begin{tabular}{|c|c|c|c|c|c|}
\hline \multirow{2}{*}{ Factors } & \multicolumn{3}{|c|}{ Priorities } & \multirow{2}{*}{$\begin{array}{c}\text { Total weighted } \\
\text { Score }\end{array}$} & \multirow{2}{*}{$\begin{array}{c}\text { Final rank } \\
\text { order }\end{array}$} \\
\hline & $\mathrm{I}$ & II & III & & \\
\hline Lineage status & 8 & 9 & 13 & 55 & \\
\hline Level of education & 23 & 17 & 15 & 118 & $\mathrm{I}$ \\
\hline Occupation & 3 & 8 & 14 & 39 & \\
\hline Assets & 4 & 11 & 10 & 44 & \\
\hline Social class & 5 & 4 & 7 & 30 & \\
\hline Affiliation with political party & 18 & 13 & 12 & 92 & III \\
\hline Age & 10 & 14 & 8 & 66 & \\
\hline Personal qualities & 19 & 15 & 11 & 98 & II \\
\hline Others & 2 & 1 & 2 & 10 & \\
\hline
\end{tabular}

Source: Field Survey, 2008

Note: Final Rank Order $=|* 3+||* 2+| I \mid * 1$

\section{Rural power structure and leadership pattern in different phases}

The present study found a significant shifting in power structure and exercise of enormous influence on rural societies in Bangladesh. Economic, social, cultural, infrastructural and political development made a radical change in the people who held the power earlier. This study reveals that the Mondal lineage enjoyed the supremacy over the general people of Sutiakhali Namapara and the neighboring village for a long time. Strong gosthi status, demographic strength, control over huge agricultural land were the sources of influence till 1970. These variables paved the way for the Mondal gosthi to hold the position of leadership informally as well as in formal Union Parisad. Education and other personal qualities were ignored in the power arenas. The situations took a radical change after the independence of the country in 1971.

The introduction of the formal government leadership, rural development projects, decentralization of administration in 80s, parliamentary system of government in 90s, activated the large scale participation to the national party politics. GO and NGOs activities and their micro credit programs expanded gradually up to the rural areas and this activities 
helped the rural people to create income generating activities. In present time, the rural power structure comprises all the new classes and groups significantly as per their active participations.

Rural power structure and leadership pattern and its changing aspects can be divided into four different phases, which are revealed below:

\section{A) 1971-1980:}

Union Parisad chairman and members were becoming the major wielders of political power in the village during 1971 to 1980 in Sutiakhali Namapara. They usually recruited their kins and fellows with the local development projects. Chairman and members of UP were the first generation kinds of the traditional informal leaders. A formal village court of the Union Parishad was introduced in 1976 named as salish adalat. This court acted as an additional arena of darbar. Though the body of salish adalat constructed by the UP members and chairman of local Union Parisad, but traditional informal persons other then UP members also participated in the rural proceedings. The power apparatus in the study village was primarily controlled absolutely by these higher lineage groups till 1980. No fresh power holders emerged other than traditional gosthi based leadership in Sutiakhali Namapara during that period.

\section{B) 1981-1990:}

The introduction of Gram Sarkar (Village Government) in October 1980 brought a change in the power structure of Sutiakhali Namapara as a new institution only. There was no significant shifting of personnel in the arena of local leadership. The Gram Sarkar office holders were also the descendents of traditional informal leaders as well. The institution of Gram Sarkar did not last due to the absence of national planning and due to various conflict situations. The introduction of Upazila Court in mid 80s brought a significant change in the adjudicative activities in the study area. This was the first well-intended change in the rural leadership pattern. The villagers said that they often went to the Upazila Court easily to settle down the unresolved cases. The informal leaders were no more for the resort of conflict. However, formal court created a negotiating class who were best known as 'tout' as they worked at the source of local police station. They, very often, used to cheat the simple villagers by affirming that they will manage the court and police on behalf of them (villagers); but the villagers found the process fake, in the long run. Villagers expressed that these 'tout' personalities were the new addition to local level politics. The traditional gosthi leaders also were maintaining a good tie with this new class to keep them in good book of the police personnel. The informal leaders of the 70 s and 80 s with their higher lineage status gradually paddled back.

\section{C) 1991-2000:}

A significant change occurred in the power structure of Sutiakhali Namapara as well as rural Bangladesh during 1991-2000, when leadership pattern also changed. From the focus group discussions it was revealed that the introduction of parliamentary system of government changed the national power structure. The most important event of this decade was the practice of democracy. The election held under the caretaker government in 1991. A democratic government came to power in 1991 after a long time in Bangladesh. The second election under the caretaker government was held in 1996. Villagers said that this practice 
ensured the proper practice of democracy in the study area. The expansion of education provided a scope for the rural people in the study village to participate in the informal power structure. Middle aged and middle educated persons were participating in the decisionmaking process during that period.

\section{D) 2001-to Date:}

The dramatic change occurred in the power structure of Sutiakhali Namapara as well as rural Bangladesh during 2001-2007, when the rural people as well as the nation also, experienced a quite different leadership shifting. The respondents said that the actual and diversified implementation of parliamentary system of government changed the national and rural political structure. Again they expressed that the implementation of micro-credit and income generating development programs in the study village by the NGOs and government organizations created a significant cash earning class in the village. The expansion of education for all also created a new opportunity to participate in the formal and informal local power structure. Young and educated persons were participating in the decision-making procedures of Sutiakhali Namapara. The local level leaders were sitting in the parliament as honorable lawmaker in one hand, and a good link between Member of Parliament (MP) and local leaders created unprecedented change, in the rural power structure on the other. A local party was more powerful than the UP chairman, members or higher lineage group, if these people had warm relations with local ruling party leaders and MP.

\section{Conclusion}

The crucial insights and findings that emerged from this study are quite surprising in the context of local power structure and village politics in Bangladesh. This study found that the rural power structure and the pattern of leadership have undergone an important change now it is not rigid as it was in the past. In the past it was dominated by institutions of lineage, Samaj and Union Parishad, and was anti poor - in all aspects it was rooted to patron clientelism. It also indicated that the traditional society represents leaders who were aged, illiterate or less educated landlords, members of influential gosthi, and their good economic standing was chiefly based on land. On the other hand leaders in recent times are younger in age, educated, members of non-influential gosthi, and they have good economic standing based on business and affiliated in the development programs and to implement these programs they maintained link with their higher ups and have had more personal qualities and they maintained a good link with major political parties. The traditional gosthi based leaderships were available during 1971- 1980 which got more flexibility during the last decade. The pattern of dependency of the poor on the power structure also changed considerably. The sources of patronage were diversified, opening up opportunities for the poor to change patronage. So, the new power structure is pro-poor. The techniques of the rural elite to build and maintain power also diversified, such as constructing business associations, building party networks and involving with non-government organizations etc. NGO-ing was a prime survival strategy of the educated elite which gave them an opportunity to secure their positions to the local power structure. In sum, it can be concluded that rural leaders with their younger age, higher education, personal qualities, political affiliation, and other traits were available to gain their ascendancy in the village power mechanism. 


\section{References}

Bourdieu, P. 1989. Social space and symbolic power. Sociological theory, pp: 7, 14-16.

Foucault, M. 1980. Power/knowledge: Selected interviews and other writings (edited by C. Gordon). New York: Pantheon Books.

Gramsci, A. 1988. The Antonio Gramsci reader: Selected readings, 1916-1935 (edited by D. Forgacs). London: Lawrence and Wishart.

Karim, A.H.M.Z. 1990. The Pattern of rural leadership in an agrarian society. Northern Book Centre: New Delhi.

Khan, S.A. 1989. The state and village society: The political economy of agricultural development in Bangladesh. Dhaka: University Press.

Lewis, D. 1991. Technologies and transactions: A study of the interaction between new technology and agrarian structure in Bangladesh. Dhaka: Centre for Social Studies.

Mozumdar, L. 2008. Changing rural power structure in a decade: A village level study in Bangladesh. Unpublished M.S. Thesis submitted to the Department of Rural Sociology, Bangladesh Agricultural University, Mymensingh.

Rahman, A. 1981. Rural power structure: A study of the local level leaders in Bangladesh: Dhaka: Bangladesh Books International.

Rahman, H.Z. 2002. Local governance: Towards a politically intelligent agenda. In Hossain Zillur Rahman and S. Aminul Islam (eds.), Local governance and community capacities: Search for new frontiers. Dhaka: UPL. (pp. 21-22).

Rowlands, J. 1995. Empowerment examined. Development in Practice I5 (2), 101-7.

Sirsikar, V.M. 1970. The Rural elite in a developing society: A study in political sociology. New Delhi: Orient Longmans Ltd. 